\title{
Internal Communications as a Factor of Company's Efficiency
}

\author{
Milica Slijepčević, Ana Bovan, Ivana Radojević
}

JEL klasifikacija: M12,O15

\section{INTRODUCTION}

As communication is important for all the members in the organization, it is extremely important to know how to communicate with managers, and in what way with employees. The methods of this communication are different depending on who the participants are, which communication channel in the organization is used and what goals should be achieved.

Effective internal communication is a precondition for achieving employee engagement, efficiency and therefore solid business results of the organization (Morris, 2010; Welch and Jackson, 2007; Jiang and Men, 2015). The significance of this form of communication is equally recognized in theory and practice. In order to achieve the desired effects and also to ensure the loyalty of the employees, organizations must pay special attention to developing and improving their model of internal communications.

It is commonly believed that internal communication represents the pillar of a strong organization. It is today also seen as an important factor contributing to the business development of the organization (Meyer 2014). Building good relationships among employees, setting certain values and rules that employees need to follow, designing strategies and goals for successful business, inspiring and motivating employees to deliver maximum results - all of these activities are a prerequisite for creating a positive business climate that affects the success of the organization. The findings of a recent research reveal that employee and internal communication management is related to employee engagement, whereby employee behaviors are directly affected and often contribute to staff renewal rate (Kanyurhi, Akonkwa 2016).

The achievement of organizational communication is measured by the degree of success in guiding activities, i.e. motivating all participants to behave in a certain way. However, in order for the organization to function, individuals and groups have to carry out their activities in a coordinated manner, effectively and efficiently, and that necessary harmonization would not be possible without communication. It is important to know how employees will interact with each other in the organization and how employees will fulfil the key roles and tasks of communication.
Abstract: The starting question in the paper is: how should the organization set itself up in the process of internal communication in order to conduct its workflow more efficiently, remain unique, recognizable and successful in a more turbulent and competitive environment? The main goal of this paper is to present contemporary trends in internal communications and how it affects efficiency in an organization. The study builds on existing literature by emphasizing the internal communication and its impact on employees and organizational efficiency.

Also, the authors present the results of the research on internal communications conducted in the insurance company Dunav osiguranje. The idea for this paper arose from the necessity of improving internal communications as to improve efficiency due to rapid technological changes and market demands. In the research, 255 respondents from all organizational units of Dunav osiguranje were surveyed. The research presented in this paper confirms the importance and relevance of the communication process with the company's employees and its impact on efficient workflow. This paper expands existing research related to the internal communication and organizational efficiency pointing the practical relevance of consistent and good employee communication and its importance for business.

Keywords: Internal communication, Employee communication, Corporate communication, Efficiency, Workflow 
In addition to the meaningful exchange of business and process tasks, communication processes also contain another interpersonal side, and successful communication has to achieve yet another goal, which is to develop mutual trust among the participants in the communication process, increase the degree of acceptance and friendship (Waters et al., 2013).

\section{LITERATURE REVIEW/ INTERNAL COMMUNICATION}

„The focus of management's attention in the last 20 years and more is communication" (Draker, 1999), while Men (2014) notes the openness in communication as one of the most desirable features of a successful leader. Building mutual trust in management-employee relations significantly influences the increase in employee commitment towards the organization, which has become one of the central subjects of the management of the organization (Men, 2015).

Internal communication can be viewed as an aspect of corporate communication in which employees in the organization exchange information with one another, with the organization and organization with them (Chalmers, 2008). This type of communication relates to a wide range of information exchange at all levels in the organization: top management and middle managers inform employees, employees themselves communicate with each other, and communication between individual departments within an organization is present also (Welch \& Jackson, 2007). Through internal communication, employees are also familiarized with the vision and the mission of the organization, it's basic values and philosophy.

Internal communication must be planned and systematically implemented, and as Sam Black points out, employee information should be effective and timely, in order to avoid the spread of rumors that are often the main source of employee information (Black, 2003). One of the features of good internal communication is to create a good working atmosphere in which positive information is transmitted, instead of rumors (Hola, 2007). The positive, truthful and real information that derives from the organization itself is very influential because its expansion strengthens the image and reputation of the company.

It is of utmost importance that internal communication is in line with the corporate culture of the organization. Adoption of a valid value system and business philosophy by employees is the key to the organization's success. Continuous application of var- ious methods and tools of internal communication ensures employee loyalty, empowers team spirit and creates desirable conditions for work (Meyer 2014). In the long term, this brings about the positive reputation of the organization not only among employees, but also among external target publics.

Analyzing the importance and role of internal communication, many theorists note that modern organizations are increasingly paying attention to improving communication with employees. Katlip, Center and Brum (2006) note that relationships with employees at all levels are the most important in the organization. Internal communication is also one of the most important tasks of public relations as a management function, which is also a „powerful instrument of socialization on the one hand and a driver of creating a positive working atmosphere on the other" (Filipovic, Kostic Stankovic, 2008). Internal communication is the foundation of an organization's culture, which is based on values, mission and work processes.

If miscommunication prevails at frequent instances, it affects work flow and disturbs the efficiency, implementation of tasks and reaching of set goals. It is more obvious in complex projects and a recent study has shown that it can be found in construction projects where there are many stakeholders (Kamalirad, Kermanshachi, Shane, Anderson, 2017). Miscommunication influences efficiency and work flow. Recent research has shown that it can have influence on the bottom line profitability. A study cited by the Society for Human Resources of USA (Buhler, Worden 2013) has come to a conclusion that miscommunication found in large companies with over 100,000 staff results in costing the company approximately $\$ 37$ billion annually. Which amounts to an average cost $\$ 62.4$ million in missed revenue per year per company. For the smaller companies of $100+$ employees miscommunication also carries a financial burden of an average of $\$ 420,000$ per year. On the other hand, a study was presented (Grossman, 2012) which indicated that specifically leader's ability to communicate capably with employees and groups within an organization reported $47 \%$ stronger profitability over a five-year period in comparison to companies of similar size but whose leaders did not display such communication skills.

The theorists are in agreement when it comes to the definition of internal communications. Internal communications can be defined as links between individuals and groups in the organization, at various levels and in different areas of specialization (Dolphin, 2005). In the same manner, one of the definitions indicates that internal communication implies any formal 
and informal communication that is internally conducted at all levels of the organization (Sincic, Polos$\mathrm{ki}$, Vokic, 2007). Some authors emphasize the fact that the communication dynamics in the organization are multi-sided and complicated, as it reflects the complex norms, values, culture and goals of the organization (Dolphin, 2005.). Thus, internal communication is a comprehensive process that includes various ways in which people interact with each other within the organization (Cornelissen, 2011).

Internal communication is directed towards employees as the target public. This target audience, which is often defined as the internal public, includes all employees in the organization. Often, both in theory and in public relations practice, it is stated that employees are the most important resource of the organization (Grunig, 1992; Grunig et al., 2002; Kim and Rhee, 2011). It is precisely because of the importance that the internal public has for the organization, it is necessary to create a positive atmosphere and relationships in the organization, which in the long run should result in high motivation and satisfaction of employees (Kanyurhi, Akonkwa 2016). Employees are frequently perceived as „ambassadors of the organization" (Dolphin, 2005), because they can best represent the values of the organization and influence the creation of its reputation in the business and wider environment.

The role of internal communication, in short, is to build and maintain good relationships with employees. Internal communication in the long run also builds confidence in the organization and its goals. The essence of internal communication is two-way communication, through which the relationships of understanding between management and employees are created and maintained. Good internal communications are the basis of good relationships in every organization. The purpose of the internal communication program, according to Filipovic and Kostic-Stankovic, is to transfer information within the organization or to build the morale of employees ,in the spirit of organization", i.e. achieving a high degree of corporate culture (Filipovic, Kostic-Stankovic, 2008).

Some of the major goals of internal communication are to create an impression that employees are a significant resource of an organization, improving relationships and understanding between employees and management, informing employees, and encouraging employees to understand and accept the organization, its culture, ethics, and organization (Sincic, et al., 2007.). It is clear that internal communication plays a crucial role in creating a spirit of community and loyalty to the organization, and therefore all activities in this domain must be planned and implemented continuously and efficiently. Internal communication must at all times be coordinated with external communication. It is believed that management should now pay equal attention to the internal and external public, while the task of communication managers is to recognize the importance of integrating internal messages with messages intended for the external public. Theorists note that in a modern business environment, the line that defines internal and external communication virtually no longer exists, which in practice means that messages directed at employees in the organization must be closely related to messages distributed to external audiences (Dolphin, 2005). Integrating different forms and levels of communication is a requirement for companies that intend to maintain themselves in an increasingly competitive market. In that sense, the harmonization of methods and tools of internal and external communication should be the priority of modern organizations (Jacobs, Yu, Chavez 2016).

Successful organizations assign great importance to diverse activities that can contribute to better communication with employees. In theory and practice it is recognized that satisfied employees are one of the greatest strategic advantages of the organization. The level of employee satisfaction and motivation is a continuous process that can be influenced by methods of internal communication and human resource management activities. Relationships with employees at different levels are a part of the public relations function, but also of human resources. These two functions are often intertwined in practice. Therefore, it is very important to differentiate the activities of internal communication with the tasks performed by the Human Resources Department. Theorists define human resources in various ways, and one of the definitions is that human resources involve "a strategic approach to employees who individually and collectively contribute to the achievement of the goals of the organization." In this sense, internal communication and human resources have a common goal, that is, to enable the organization to achieve efficiency and business results by mobilizing in the right way its key resource, and that is its employees.

Human resources and internal communication have several common features. First, both functions are essential to achieving the goals of the organization and are strategically related to business results. In addition, both human resources and internal communication are directed at employees as the organization's 
most important resource, and both functions aim to create satisfied and loyal employees. The permeation of human resources with the function of public relations comes primarily from the field of communication with employees. According to Katlip, Senter and Brum (2006), the question of who needs to control communication with employees is the most common cause of conflicts between the two functions (Katlip, et al., 2006).

In theory, there are three approaches to this problem. According to one school of thought, internal communications are the duty of human resources department rather than public relations, because human resources have an integrated approach to employees and from this function it is best to understand what employees need (Sincic, et al., 2007). The second approach implies that the boundaries between internal communication and human resources are not clear and that it is not possible to accurately determine what the task is of each one, while the third position insists on the necessity of linking human resources management and communication skills, that is, internal communications, for the benefit of the organization (Mishra, Boynton, Mishra, 2014).

Business practice has shown that, at the time of the many changes that organizations are facing today, public relations and human resources functions need to work even closer and more intensively. The result of this collaboration should be to find the best and most effective solutions that will enable the organization to achieve the set goals due to its employees. „An organization does not exist without people, and relations among people do not exist without communication" (Mikic, 2010).

\section{METHODOLOGY}

Communication is a very complex process and it is therefore of utmost importance to identify the factors that influence the effectiveness of internal communication and their interconnection, or interdependence. The complexity of the subject of research required the need to perceive and consider the problems in the existing literature and theoretical approaches to its understanding, as well as practical research in the field of public relations and organizational culture. The results of the research pointed to the contribution of quality communication mechanisms to reducing the degree of uncertainty in understanding messages which affect efficiency.
The aim of the research is to determine the relevant factors influencing the functionality of internal communications in the organization based on a scientifically based methodology. The tasks set out were to determine what type of employee behavior contributes to more efficient integrated communication, what management style contributes to integrated communication, and what kind of communication is an incentive for the development and performance of an organization's business.

The purpose of the conducted research is to create a model of communication that would uniquely focus internal communication towards the efficient and successful functioning of the organization.

In accordance with the stated objective and tasks of the research, as well as insight into the existing literature, it is possible to set the following general hypothesis:

H0: Internal communication contributes to the efficiency and success of the organization's functioning.

Individual hypotheses:

H1: Internal communication is clearly focused on the goals of the organization.

H2: Leaders behavior affects the communication and employee efficiency

H3: The working atmosphere needs to be supportive and constructive in order to provide for efficiency.

\section{RESULTS OF THE RESEARCH AND DISCUSSION}

In the research conducted in the insurance company Dunav osiguranje (est. 1945.) 255 respondents from all organizational units, gender, levels of education, age and type of workplace were surveyed, of which valid questionnaires were 250 (98\%). The survey was conducted through a written questionnaire, in direct contact with the respondents, where the respondents gave answers without the help of the interviewers. The questionnaire as a research instrument has been compiled in accordance with the subject and purpose of the research.

Respondents responded to Likert's type questions in the form of a scale of attitudes (responses 1 to 5, where 1 is a negative assessment „I completely do not agree“ to grade 5 as a positive grade „I completely agree"). In total, 65 questions were asked, of which 6 questions related to the demographic characteristics 


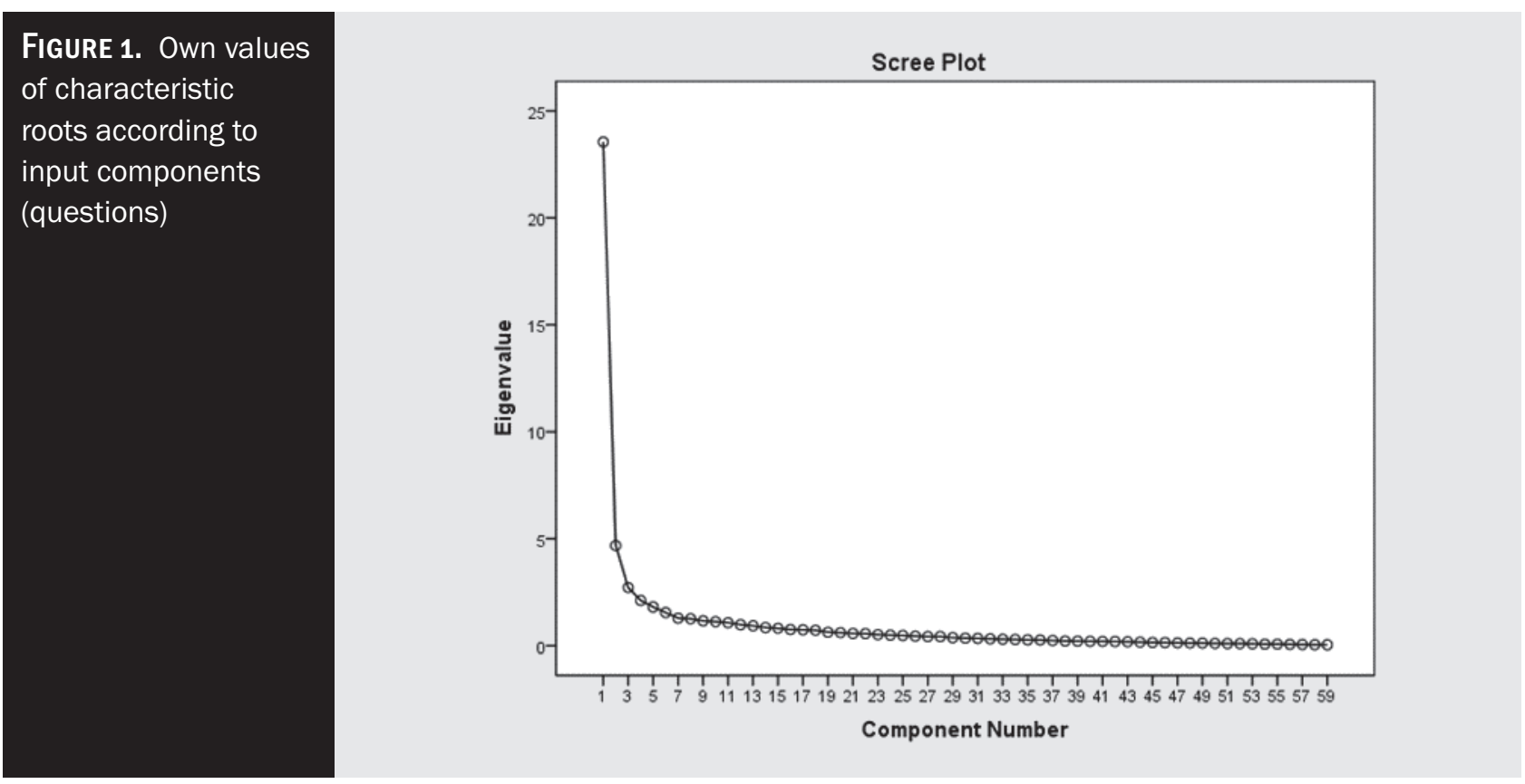

of the respondents, while 59 questions related to the internal and external communication of employees. In order to process data, the SPSS statistical package was used.

Gender wise female were 57.8\%, the rest male; highly educated staff, master's and Doctor of Science were $64 \%$; educated in the field of social sciences were $40.2 \%$, the largest part of survey respondents was of the age between 25 and 55 years; performing jobs at the operational working level 43\%; and of the executive level 38\%; average length of stay in company was 9.18 years with a standard deviation of 3.36 years. The data indicate that these are employees who have a high level of awareness of the importance of communication. Over $70 \%$ of respondents stated that they generally agree or agree with the claims that good communication contributes to success, that it motivates and stimulates, serves to overcome the problems, is a prerequisite for profitability, and that it is important that all employees know the vision and mission of the organization.

\subsection{Factor analysis}

Using the methodology of factor analysis, using the Euclidean distance and Varimax rotation, results were obtained as indicators of the main factors, i.e. an analysis of the main components on the correlation matrix was carried out. In the extraction of communality, the factor analysis highlights the positive attitude of employees towards vertical communication (senior - subordinates), as well as horizontal communication (peer to peer relations).

Out of a total of 59 questions (factors), 11 were extracted which led to a decrease in the dimension of the problem by $81 \%$, with a total of $18.644 \%$ of newly generated variables explaining $71.789 \%$ of the variabilities. The gain achieved by this approach to the consideration of the problem led to the improvement of the quality of the stated results as many as 4 times $(71.789 \% / 18.644 \%=3.851)$. The analysis of the results was carried out on the values of the factors after the rotation and it is noted that $50 \%$ of the variability is contained in the first 4 factors. The significance of the other seven factors is defined on the basis of the Kaiser criterion, i.e. at the level of characteristic roots larger than one. The significance of factors 5 to 11 is at the level of 4.3 to $2.3 \%$. Graph 1 shows the values of characteristic roots for all 59 questions. It is noted that the first crossover point is between the fourth and fifth factors, while the second crossover point is more difficult to spot (between factors 11 and 12) due to the small values of the variability achieved.

The level of interconnectedness of the observed questions and the factors obtained in the process of factor analysis, after the factor rotation, in order to obtain the maximum load of parameters on the given factors, is shown in Table 1. The total results are presented for 59 questions and 11 factors. The values of correlation coefficients are ranked according to the significance of the load of individual factors. 
TABLE 1: Coefficient of correlation between the observed parameters (questions) and the factors obtained

\begin{tabular}{|c|c|c|c|c|c|c|c|c|c|c|c|c|}
\hline & & & & & ctors & & & & & & & \\
\hline No & Question & 1 & 2 & 3 & 4 & 5 & 6 & 7 & 8 & 9 & 10 & 11 \\
\hline Varial & bility \% & 29.808 & 9.255 & 5.965 & 5.827 & 4.279 & 3.591 & 3.016 & 2.754 & 2.675 & 2.318 & 2.302 \\
\hline Cumu & ulative $\%$ & 29.808 & 39.063 & 45.027 & 50.855 & 55.133 & 58.725 & 61.740 & 64.494 & 67.169 & 69.487 & 71.789 \\
\hline 1 & $\begin{array}{l}57 \text { Talk about oneself } \\
\text { with humour and accepts } \\
\text { criticism }\end{array}$ & .863 & .097 & -.040 & .144 & -.003 & -.136 & -.017 & -.027 & .187 & -.016 & -.018 \\
\hline 1 & $\begin{array}{l}51 \text { Good Communication } \\
\text { (GC) contributes to success }\end{array}$ & .854 & .200 & .024 & .231 & .011 & .031 & .068 & -.007 & .019 & -.042 & -.063 \\
\hline 1 & 39 Admits a mistake & .843 & .118 & -.013 & .071 & .049 & .174 & .041 & -.002 & .171 & -.039 & .096 \\
\hline 1 & $\begin{array}{l}42 \text { Has a clear vision and } \\
\text { plan }\end{array}$ & .833 & .127 & -.041 & .210 & -.017 & .176 & .097 & -.042 & -.060 & .047 & .123 \\
\hline 1 & $\begin{array}{l}52 \mathrm{GC} \text { motivates and } \\
\text { stimulates }\end{array}$ & .829 & .187 & -.065 & .236 & .018 & .089 & .001 & .033 & -.003 & -.066 & -.002 \\
\hline 1 & $\begin{array}{l}41 \text { Stimulates a friendly } \\
\text { atmosphere }\end{array}$ & .817 & .215 & -.174 & .200 & .064 & .195 & -.054 & -.040 & -.091 & .040 & .027 \\
\hline 1 & 40 Cooperates successfully & .799 & .134 & -.154 & .059 & .169 & .153 & -.032 & -.171 & .014 & .082 & .077 \\
\hline 1 & $\begin{array}{l}50 \text { Values meaningfull } \\
\text { communication }\end{array}$ & .780 & .124 & .201 & .179 & .041 & -.080 & .118 & -.022 & .129 & -.067 & .048 \\
\hline 1 & 43 Stimuates learning & .773 & .282 & -.134 & .060 & .217 & .012 & -.003 & -.063 & .053 & -.104 & -.186 \\
\hline 1 & $\begin{array}{l}46 \text { Listens to different } \\
\text { opinions }\end{array}$ & .769 & .196 & -.210 & .167 & .170 & .248 & -.176 & .037 & -.104 & .006 & .051 \\
\hline 1 & 36 Allows making decisions & .762 & .300 & -.050 & .042 & -.020 & .059 & -.008 & .155 & .069 & .113 & -.144 \\
\hline 1 & $\begin{array}{l}47 \text { Allows expression of } \\
\text { opinions }\end{array}$ & .744 & .180 & -.153 & -.036 & .202 & .148 & -.135 & .064 & -.084 & -.073 & -.086 \\
\hline 1 & $\begin{array}{l}56 \text { Everyone knows the } \\
\text { strategy }\end{array}$ & .726 & .107 & -.011 & .284 & -.044 & -.171 & .116 & .114 & .091 & .030 & .011 \\
\hline 1 & $\begin{array}{l}55 \text { Everyone knows the } \\
\text { vision and mission }\end{array}$ & .718 & .137 & -.126 & .242 & .041 & -.097 & .083 & .201 & -.002 & .080 & -.001 \\
\hline 1 & $\begin{array}{l}38 \text { Short term goals with the } \\
\text { vision }\end{array}$ & .716 & .308 & .053 & .119 & .076 & -.008 & .127 & .079 & .011 & .276 & .017 \\
\hline 1 & 33 Deliberates work goals & .711 & .224 & .034 & .206 & -.028 & .261 & .149 & .127 & -.084 & .070 & .025 \\
\hline 1 & 27 Helps the subordinates & .708 & .224 & -.163 & .161 & .136 & .148 & .026 & .016 & .033 & .244 & -.121 \\
\hline 1 & $\begin{array}{l}24 \text { Open for two-way } \\
\text { communication }\end{array}$ & .705 & .285 & -.321 & .204 & .079 & .095 & -.149 & -.039 & .012 & .121 & .002 \\
\hline 1 & $\begin{array}{l}35 \text { Communication } \\
\text { capabilities as an assest }\end{array}$ & .647 & .415 & -.036 & .157 & .010 & .042 & -.001 & .123 & .168 & -.002 & .025 \\
\hline 1 & $\begin{array}{l}31 \text { Nonverbal messages are } \\
\text { clear }\end{array}$ & .620 & .114 & -.371 & -.025 & .059 & .460 & .122 & .029 & .057 & .111 & -.024 \\
\hline 1 & 34 Shares the news & .618 & .564 & -.115 & .060 & -.077 & .008 & .121 & .049 & .062 & -.083 & -.020 \\
\hline 1 & $\begin{array}{l}28 \text { Promotes own and ideas } \\
\text { of others }\end{array}$ & .595 & .360 & -.049 & .197 & -.109 & .036 & -.043 & .344 & .068 & .084 & -.147 \\
\hline 1 & 18 Praises associates & .592 & .475 & -.080 & .247 & -.064 & .059 & -.152 & -.004 & .075 & .224 & -.031 \\
\hline 1 & $\begin{array}{l}44 \text { Associates are aware of } \\
\text { the problems }\end{array}$ & .590 & .248 & -.108 & .066 & .148 & -.114 & -.053 & .058 & .194 & .143 & .090 \\
\hline 1 & 48 Consistent positions & .575 & .014 & .444 & -.057 & .001 & .015 & .016 & .105 & .111 & -.034 & -.120 \\
\hline 1 & $\begin{array}{l}19 \text { Consults with the } \\
\text { subordinates }\end{array}$ & .571 & .511 & -.152 & -.020 & .099 & .210 & -.197 & .080 & .014 & .037 & -.115 \\
\hline 1 & $\begin{array}{l}15 \text { Listens to the problems } \\
\text { of other colleagues }\end{array}$ & .564 & .525 & -.083 & .098 & .043 & .213 & -.285 & .014 & .093 & .029 & .059 \\
\hline 1 & $\begin{array}{l}14 \text { Time for informal } \\
\text { socialising }\end{array}$ & .546 & .384 & .068 & .031 & -.020 & .036 & -.020 & .216 & .199 & .046 & .181 \\
\hline 1 & $\begin{array}{l}25 \text { Determines the role of } \\
\text { the team members }\end{array}$ & .463 & .452 & -.085 & .312 & .069 & .179 & -.039 & -.012 & .197 & .312 & -.167 \\
\hline 1 & $\begin{array}{l}32 \text { Well set golas and } \\
\text { priorities }\end{array}$ & .458 & .277 & .202 & .230 & -.048 & .244 & .441 & .114 & -.120 & -.027 & .209 \\
\hline 1 & $\begin{array}{l}10 \text { Open for different } \\
\text { opinions }\end{array}$ & .444 & .042 & -.126 & .048 & .292 & .282 & -.317 & .173 & .131 & -.238 & .299 \\
\hline
\end{tabular}




\begin{tabular}{|c|c|c|c|c|c|c|c|c|c|c|c|c|}
\hline \multicolumn{13}{|c|}{ Factors } \\
\hline No & Question & 1 & 2 & 3 & 4 & 5 & 6 & 7 & 8 & 9 & 10 & 11 \\
\hline 2 & $\begin{array}{l}12 \mathrm{RI} \text { about company } \\
\text { operations }\end{array}$ & .386 & .685 & .009 & .181 & .104 & -.003 & .353 & -.009 & -.035 & -.006 & .039 \\
\hline 2 & $\begin{array}{l}11 \mathrm{RI} \text { about finalization of } \\
\text { workflow }\end{array}$ & .453 & .681 & .003 & .247 & .058 & .188 & .163 & -.064 & -.087 & .018 & .010 \\
\hline 2 & $\begin{array}{l}16 \text { The whole team makes } \\
\text { important decisions }\end{array}$ & .560 & .647 & -.087 & .027 & .186 & .000 & .045 & -.003 & .017 & .018 & -.036 \\
\hline 2 & 20 Speaks the truth & .416 & .640 & -.096 & .262 & .029 & .018 & .021 & -.186 & .127 & .107 & .008 \\
\hline 2 & $\begin{array}{l}13 \text { Gets ideas from the } \\
\text { subordinates }\end{array}$ & .483 & .552 & .018 & -.031 & .253 & .031 & .008 & .219 & .056 & -.219 & .044 \\
\hline 2 & $\begin{array}{l}23 \text { Shares opinions with } \\
\text { others on a regular basis }\end{array}$ & .471 & .524 & .051 & .295 & -.083 & .121 & .124 & .007 & .094 & .111 & .133 \\
\hline 3 & $\begin{array}{l}45 \text { Would communicate with } \\
\text { difficulty if did not have such } \\
\text { a position }\end{array}$ & -.178 & -.133 & .770 & .067 & .068 & -.100 & .149 & .089 & -.100 & -.163 & -.026 \\
\hline 3 & $\begin{array}{l}22 \text { Closed and not open for } \\
\text { communication }\end{array}$ & -.178 & .068 & .735 & -.002 & .112 & -.044 & -.009 & -.057 & .026 & .189 & .167 \\
\hline 3 & $\begin{array}{l}37 \text { Announcing the privilege } \\
\text { statements }\end{array}$ & -.084 & -.211 & .703 & .107 & -.055 & .140 & .075 & -.062 & .014 & .003 & .144 \\
\hline 3 & $\begin{array}{l}30 \text { Gives orders rather than } \\
\text { suggestions }\end{array}$ & -.289 & .124 & .601 & .020 & -.101 & .326 & .111 & .083 & .218 & .102 & -.048 \\
\hline 4 & $\begin{array}{l}54 \text { GC Conditions for } \\
\text { profitability }\end{array}$ & .358 & .163 & .082 & .763 & .095 & .084 & .008 & .252 & -.002 & -.009 & -.095 \\
\hline 4 & $\begin{array}{l}53 \mathrm{GC} \text { for overcoming } \\
\text { problems }\end{array}$ & .325 & .165 & .030 & .737 & .165 & .248 & .011 & .028 & -.062 & -109 & -.028 \\
\hline 4 & $\begin{array}{l}59 \text { Clear stating of attitudes } \\
\text { in a conflict }\end{array}$ & .397 & .318 & .051 & .662 & .038 & .179 & .025 & -.043 & .098 & .141 & -.056 \\
\hline 4 & $\begin{array}{l}58 \text { Humor in overcoming } \\
\text { disagreements }\end{array}$ & .403 & .073 & .246 & .607 & .012 & -.001 & .228 & -.028 & .164 & .141 & .244 \\
\hline 5 & $\begin{array}{l}07 \text { Precise written } \\
\text { communication for better } \\
\text { efficiency }\end{array}$ & .164 & .106 & -.169 & .174 & .685 & .266 & -.031 & .108 & .234 & -.088 & .120 \\
\hline 5 & 09 Questions asked upfront & .003 & .042 & .150 & -.044 & .653 & -.136 & -.012 & .078 & -.010 & .295 & .228 \\
\hline 5 & $\begin{array}{l}06 \text { Precise corporate dress } \\
\text { rules }\end{array}$ & .067 & -.126 & .020 & -.046 & .609 & .126 & .349 & .018 & .396 & .038 & -.123 \\
\hline 5 & 01 Plan of communication & .012 & .121 & .004 & .202 & .526 & -.015 & -.061 & .444 & -.096 & -.056 & .133 \\
\hline 5 & $\begin{array}{l}49 \text { Does not decide before } \\
\text { the top management } \\
\text { decision }\end{array}$ & .309 & .193 & .329 & .211 & .501 & .020 & .060 & -.098 & -.073 & -.139 & -.249 \\
\hline 6 & 21 Respecting the standard & .287 & .169 & .118 & .305 & .073 & .664 & .196 & -.057 & .040 & -.016 & -.071 \\
\hline 6 & 17 Staff under control & .068 & .075 & .365 & .266 & .093 & .550 & .108 & .108 & .008 & .208 & .063 \\
\hline 7 & $\begin{array}{l}26 \text { Sanctions for the } \\
\text { indolent workers }\end{array}$ & .008 & .119 & .411 & .125 & .031 & .222 & .661 & -.089 & -.021 & .044 & .004 \\
\hline 7 & $\begin{array}{l}05 \text { Nonverbal } \\
\text { communication }\end{array}$ & -.059 & .178 & .040 & -.011 & .274 & .108 & .482 & .471 & .194 & .044 & .169 \\
\hline 8 & $\begin{array}{l}02 \text { Avoiding foreign } \\
\text { expressions }\end{array}$ & .285 & -.138 & -.047 & .192 & .155 & -.028 & -.082 & .603 & .339 & -.054 & .031 \\
\hline 8 & 04 Self power & .018 & -.162 & .336 & -.184 & .185 & .139 & .129 & .448 & -.231 & .433 & .080 \\
\hline 9 & $\begin{array}{l}03 \text { More listening than } \\
\text { speaking }\end{array}$ & .195 & .147 & .067 & .046 & .159 & .032 & .000 & .112 & .811 & -.037 & .045 \\
\hline 10 & $\begin{array}{l}29 \text { Plan of activities for the } \\
\text { subordinates }\end{array}$ & .503 & .145 & .063 & .127 & .050 & .149 & .044 & -.059 & -.022 & .584 & .010 \\
\hline 11 & 08 Informal communication & -.029 & .017 & .176 & -.027 & .154 & -.013 & .057 & .073 & .022 & .014 & .792 \\
\hline
\end{tabular}

By insight in Table 1. based on the coefficient of correlation, assignment of characteristics of the obtained factors was performed. The grouping of parameters was carried out according to the maximum load that was achieved in relation to the given factors. The results of the correlation analysis between the factors and the observed variables generated the following characteristics of the factors given in Table 2. The 
TABLE 2: Factor characteristics

\begin{tabular}{|c|c|c|l|}
\hline Factors & Variability \% & Gumulative \% & Characteristics \\
\hline 1 & 29.808 & 29.808 & Profile of desired manager \\
\hline 2 & 9.255 & 39.063 & Team management \\
\hline 3 & 5.965 & 45.027 & Tyrant \\
\hline 4 & 5.827 & 50.855 & Solving communication problems \\
\hline 5 & 4.279 & 55.133 & Rigid communication (formal) \\
\hline 6 & 3.591 & 58.725 & Control, adheres strictly to the rules \\
\hline 7 & 3.016 & 61.740 & Strict and just \\
\hline 8 & 2.754 & 64.494 & Authoritative and clear \\
\hline 10 & 2.675 & 67.169 & More listening than speaking \\
\hline 11 & 2.318 & 69.487 & Plan of activities for the subordinates \\
\hline
\end{tabular}

first factor that brings with it more than $29 \%$ of weight reflects the profile of the desired manager - peer colleague. The first factor builds a total of 31 variables (questions) although such a large number of questions can cause a problem in interpreting the results obtained, in this case it can be said that these questions express the appearance of the perfect manager, the one whom their subordinates want, and above all what they want to see from a manager. The first factor can be used to build the basic profile characteristics of future executives.

Employees expect from their executives that their relationships functions on the basis of team management. They expect the manager to inform them of the situation in the organization, so to improve their efficiency and results, be open to accept their opinions

FigurE 2. Answers to questions 1 - 5

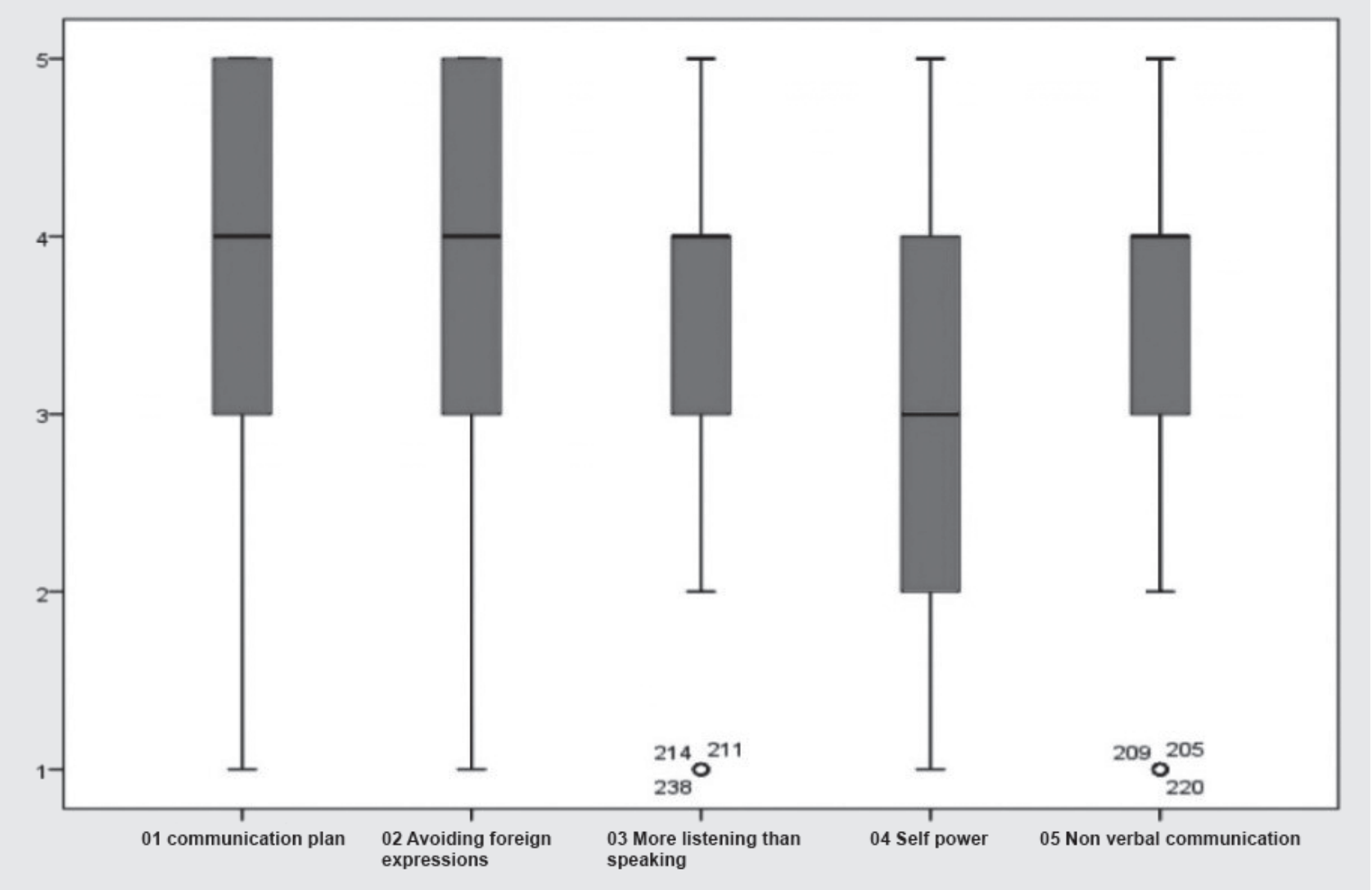


FigurE 3. Answers to questions 6 - 10

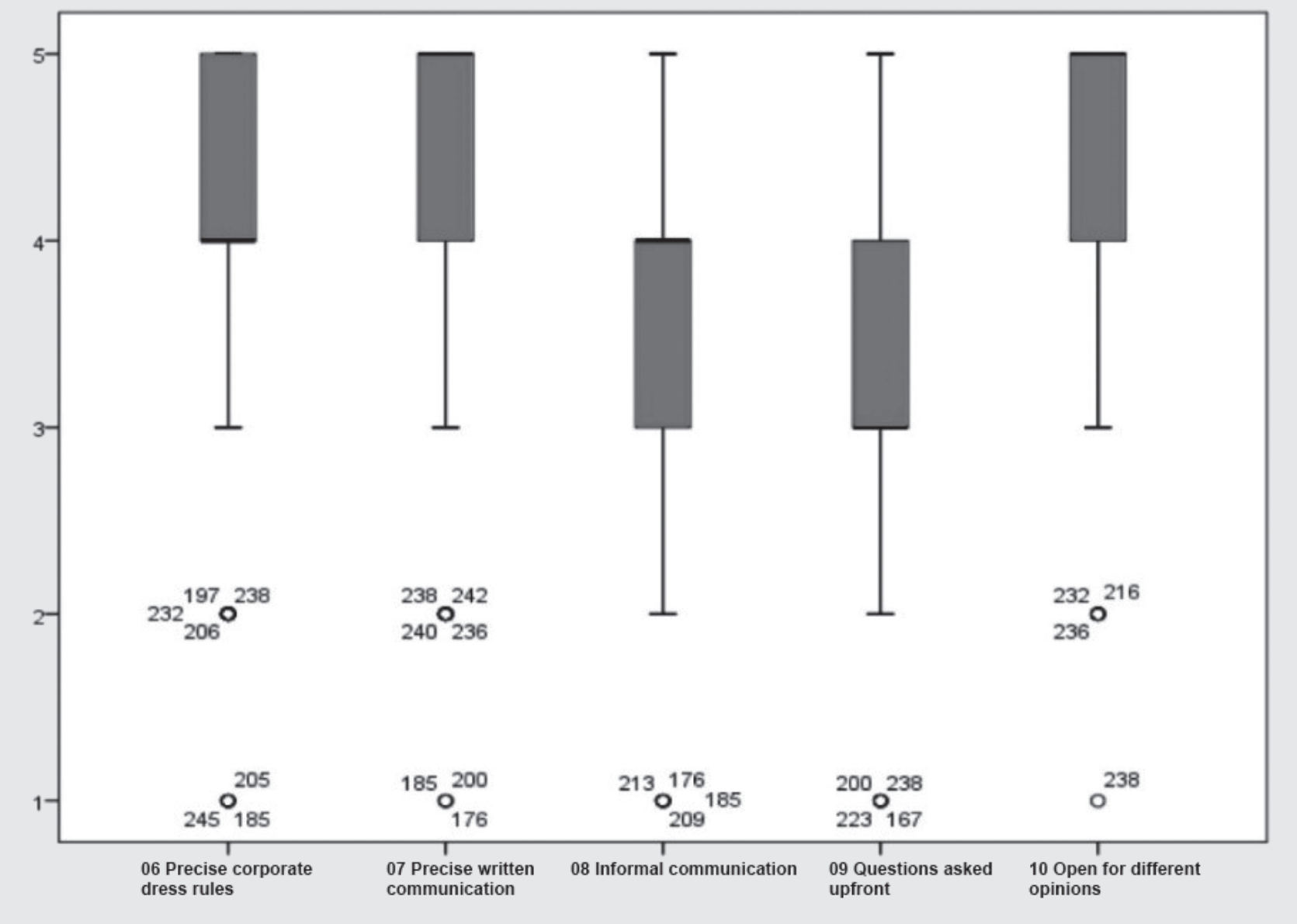

and exchange mutual experiences. The characteristics thus obtained can be used to build a profile of a responsible manager, who will respect employee attitudes, and the same time they will be appreciated by the staff. In this way, efficiency can be achieved, the employees would deliver better results, and the manager would reach the goals for which he is appointed.

The results of the research were analyzed through general and individual hypotheses confirming or denying the starting assumptions in the research of the defined problems.

H1 - Internal communication is clearly focused on the goals of the organization.

In the questions from 1 to 5 , the median response was 4 , i.e. „I generally agree“, while to the question 4 median was 3, i.e. „I mostly disagree“. In Question 4, most of the answers tended towards the negative connotation.

Below we will list the questions used in the research. For a successful internal communication company must: question 1- make a communication plan; question 2 - avoid using foreign words and expressions; question 3 - always listen more than talk; question 4 - highlight your own power and importance; question 5 - pay great attention to nonverbal communication.

Question block from 6 to 10 was evaluated with a large variance among the respondents, so that the median question 6 was 4, for Question 7 it was 5 „I agree", and for the question 8 median is 4 , question 9 is 3 and question 10 is 5 . As it can be seen, in questions 7 and 10, the respondents expressed a very positive attitude, while the question 9 caused negative feelings and attitudes.

Questions used in this block are following: For a successful internal communication company must: question 6 - Precise knowledge of the rules of business dress code; question 7 - Precise knowledge of the written forms of communication; question 8 - Pay much attention to informal communication; question 9 Have pre-asked questions and answers; question 10 Be ready and open to different opinions and attitudes. 


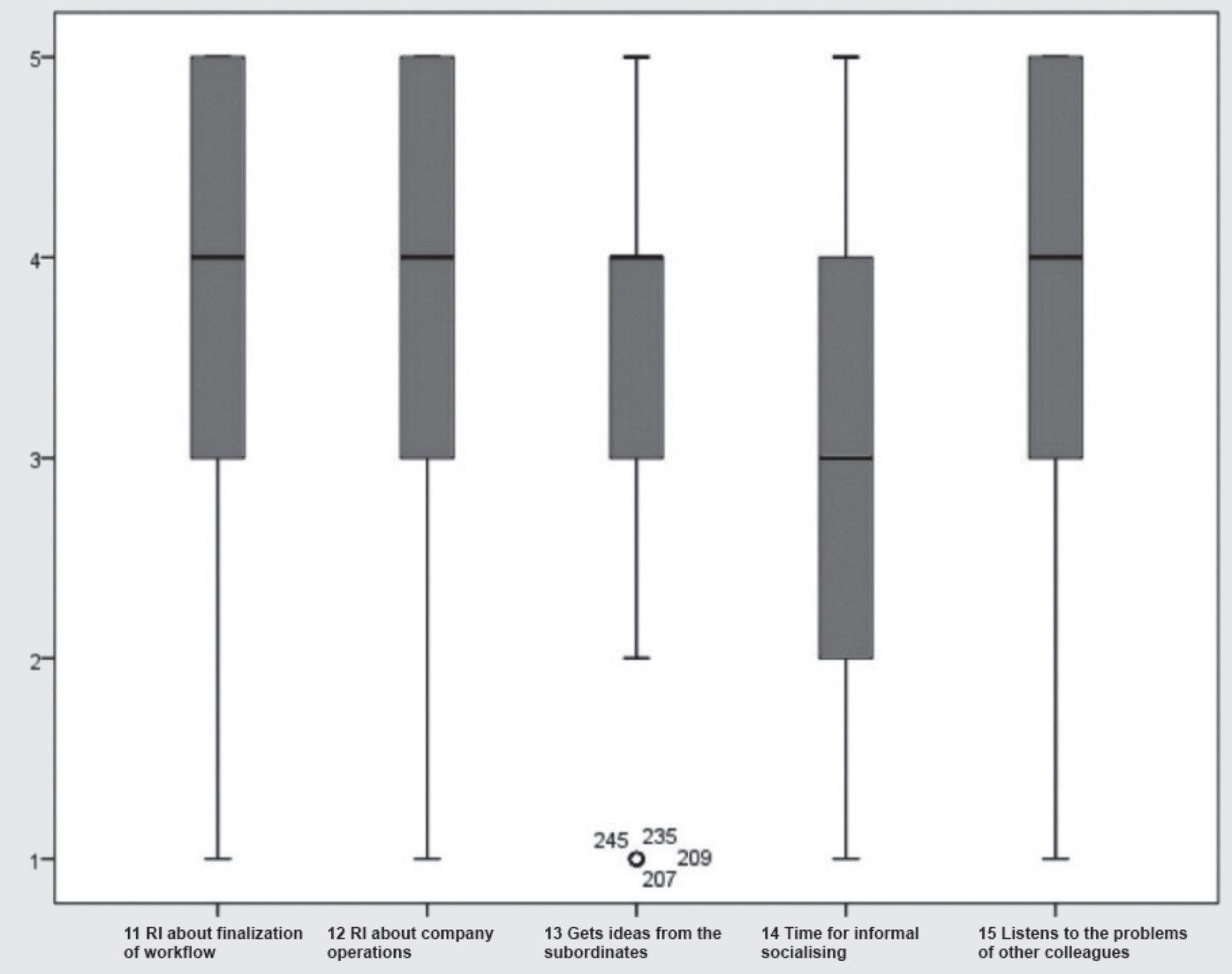

$\mathrm{H} 2$ : Leaders behavior affects the communication and employee efficiency

The questions from 11 to 15 deals with standard functional operational communication of the managers with their employees. In all cases, the median value was 4 , except for question 14 where the respondents again voiced negative opinions, i.e. the manager had no time for informal socializing (the median was $\mathrm{Me}=3)$.

Questions used in this block are following: CLAIM - The superior communicates in my organization by doing so: question 11 - Regularly inform us about the overall realization of the given tasks; question 12 - Regularly inform us about the overall company business through official reports; question 13 - He gets clear ideas and suggestions from his subordinates; question 14 - He set the time for informal socializing with his employees; question 15 - It is time to hear the concerns and worries of your colleagues.

Questions from 16 to 20 had uniform answers, the median was $4(\mathrm{Me}=4)$. The respondents gave more positive and less dissimilar answers to questions 17 and 20.

Questions used in this block are following: CLAIM - The superior communicates in my organization by doing so: question 16 - Keep in mind that most important decisions are made by the whole team; question 17 - It strives to keep its staff under control; question 18 - Immediately boast an associate who works well; question 19 - Consult his subordinates when they encounter a problem; question 20 - He's telling the truth.

Questions from 21 to 25 brought a wide range of attitudes of the respondents. In answer to question 21 respondents gave a maximum score of $5(\mathrm{Me}=5)$, question 22 caused the opposite effects where most 


\section{marketing}

FigurE 5. Answers to questions $16-20$

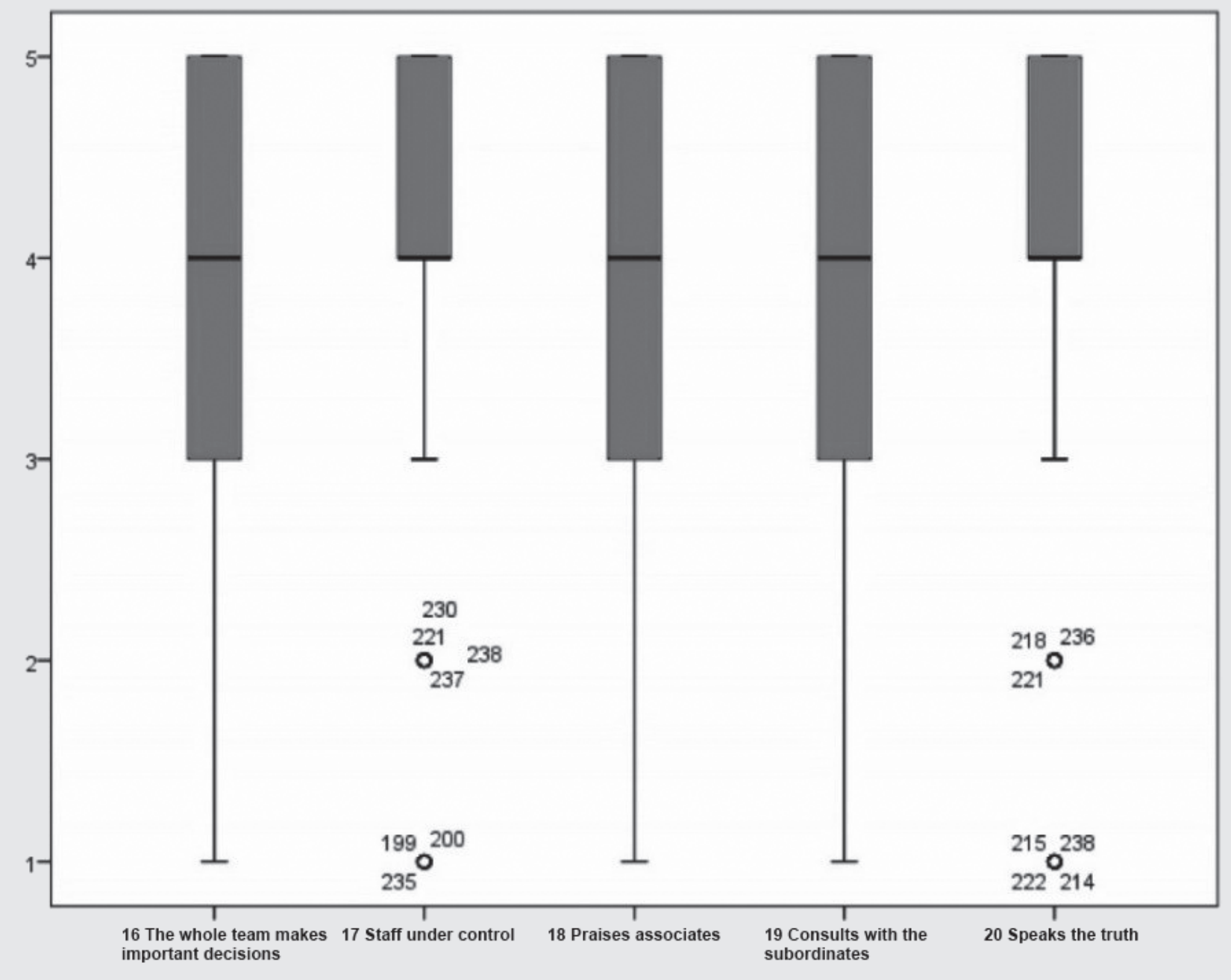

of the respondents expressed very negative opinions $(\mathrm{Me}=2)$ with the answer „I do not agree“. The other three questions 23, 24 and 25 respondents were on the expected $\mathrm{Me}=4$. It can be pointed out that question 23 despite having the $\mathrm{Me}=4$ answers, still had has a slightly lower percentage of agreement among respondents on ,attitudes about senior managers.

Questions used in this block are following: CLAIM - The superior communicates in my organization by doing so: question 21 - Asks subordinates to comply with standards, rules and procedures; question 22 - It is closed and is not communicative; question 23 - He regularly communicates its opinion to employees; question 24 - It is open for two-way communication, showing concern for the well-being of employees; question 25 - Determines the role and responsibilities of each team member.
Within the set of questions 26 to 30 , two questions 26 and 30 differentiate themselves receiving negative connotation, i.e. $\mathrm{Me}=3$, while questions from 27 to 29 are at a stable level $\mathrm{Me}=4$. Some more positive answers were received to question 27 .

Questions used in this block are following: CLAIM - In our organization my manager internally communicates by doing so: question 26 - He applies sanctions to those who achieve poor results; question 27 - Helps subordinates to overcome the problems that hinder them in performing tasks; question 28 - He has tendency is to promote the ideas of his colleagues to the same extent as his own; question 29 - He makes plan of activities for their subordinates; question 30 What he wants to be done he expressed in the form of an order rather than in the form of a suggestion.

The questions 31 to 35 were in all cases at a stable level of agreement $\mathrm{Me}=4$, with questions 32 and 33 


\section{FiguRE 6. Answers to questions $21-25$}

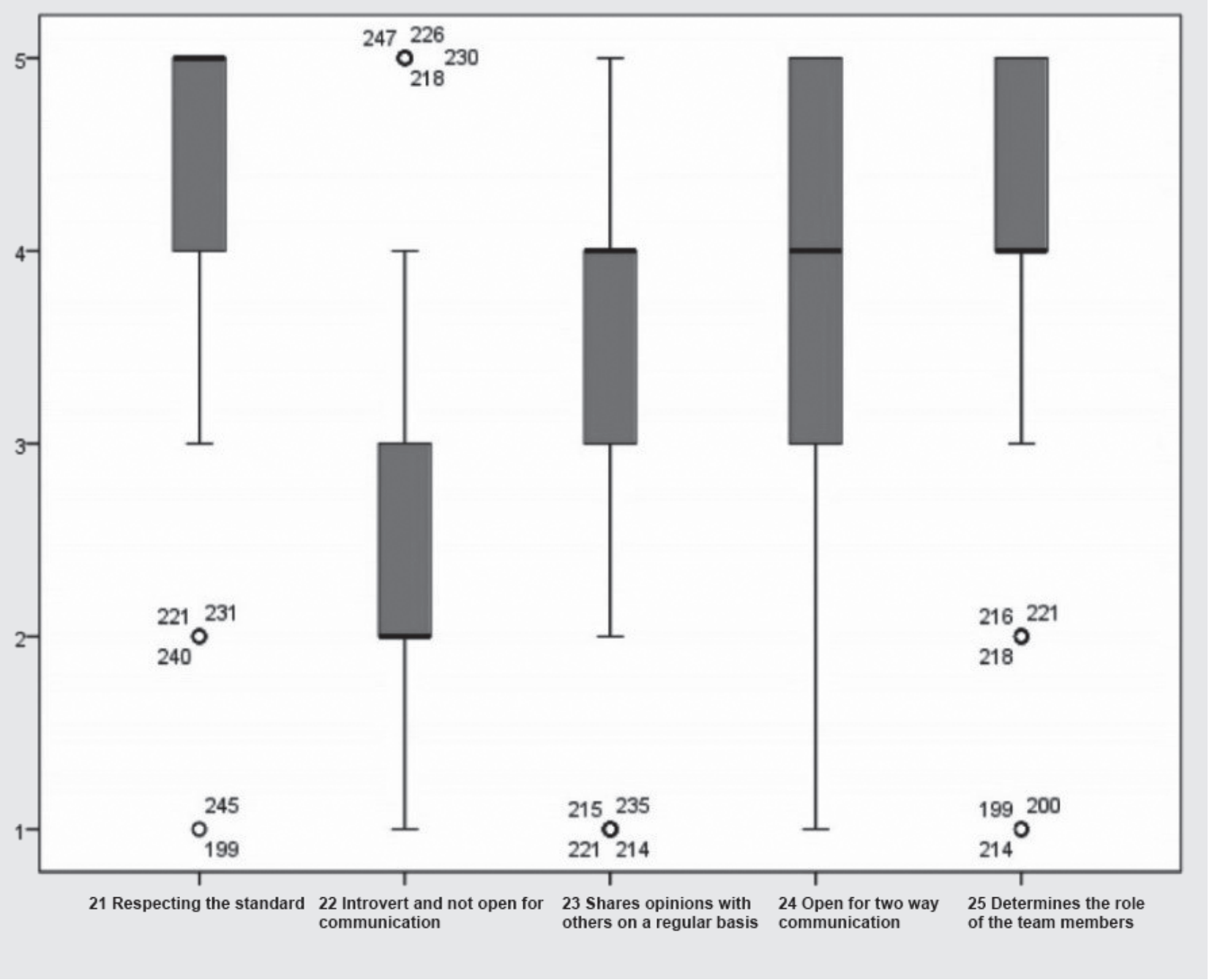

receiving a somewhat more positive attitude from the other questions in this group.

Questions used in this block are following: CLAIM - In our organization my manager internally communicates by doing so: question 31 - His written, spoken and non-verbal messages are clear, short and well accepted; question 32 - The organization is successful thanks to well-defined goals and defined priorities; question 33 - It reviews work goals and determines whether they are being realized; question 34 - When a new innovation comes, he comes out to employees and announces the news; question 35 - Recognizes communication as a competitive advantage.

Questions 36 to 40 reached the median $\mathrm{Me}=4$ value, except for question 37 where it was $\mathrm{Me}=3$. The distribution of the answers is balanced in questions 36,39 and 40 , while the more negative attitude is rep- resented mostly in question 37 and somewhat less negative in the question 38 .

Questions used in this block are following: CLAIM - In our organization my manager internally communicates by doing so: question 36 - Allows employees to make certain decisions in order to avoid time wasting; question 37 - Presenting attitudes is the privilege of only certain groups of people; question 38 - It links short-term work goals with a vision that inspires; question 39 - It is able to admit the mistake if it is made; question 40 - Successfully cooperates with the most diverse people.

$\mathrm{H} 3$ - The working atmosphere needs to be supportive and constructive in order to provide for efficiency.

Questions 41, 42 and 43 have a clear distinction in supporting the attitudes at the $\mathrm{Me}=4$ level, while the question 44, although it has the same value of the 


\section{marketing}

FigurE 7. Answers to questions $26-30$

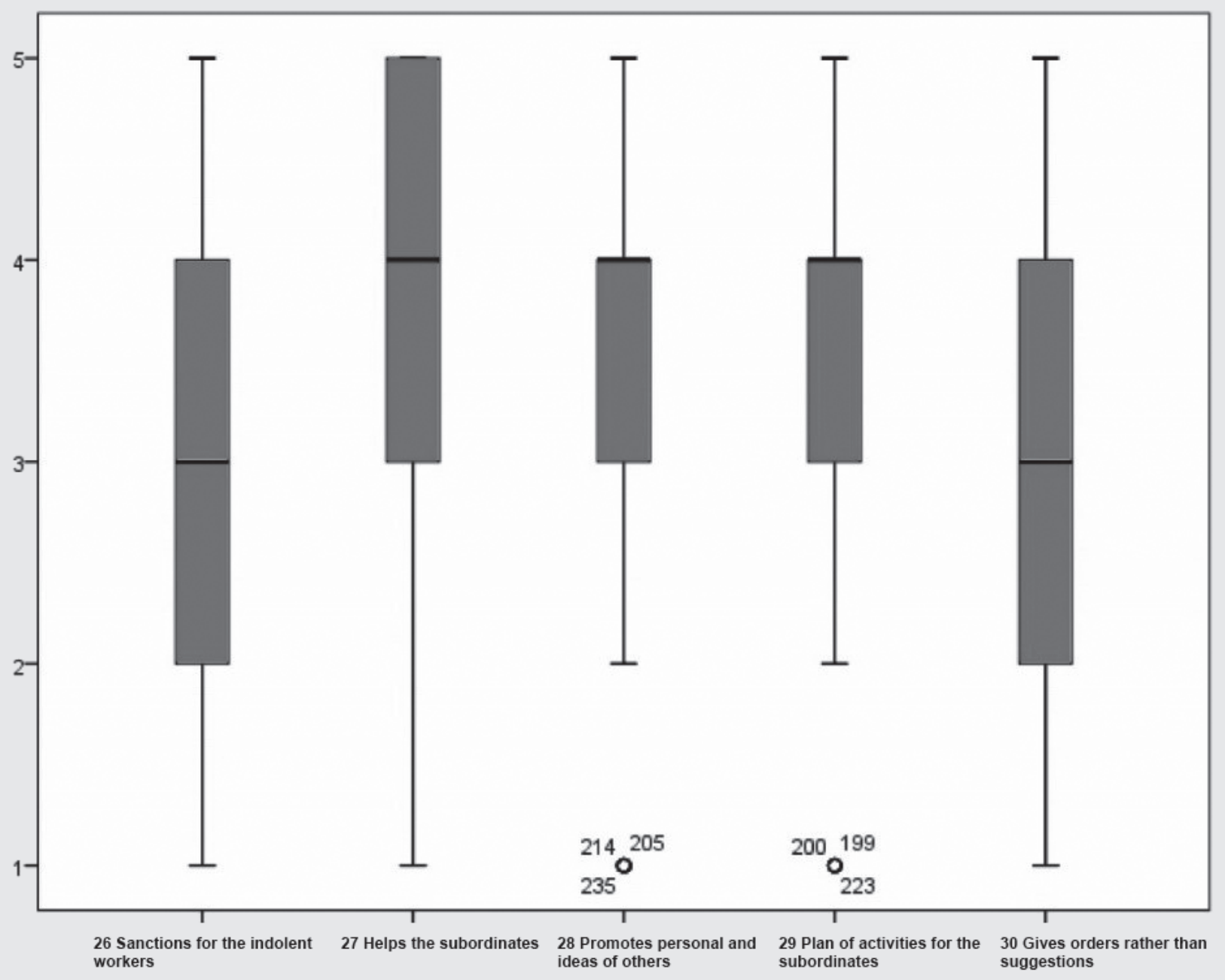

median, $\mathrm{Me}=4$ received somewhat more negative attitudes, while the question 45 caused some negative attitudes with the median $\mathrm{Me}=3$.

Questions used in this block are following: CLAIM - In our organization my manager internally communicates by doing so: question 41 - Accepts the feelings and attitudes of employees and encourages a friendly atmosphere; question 42 - It has a clear vision, and a work plan; question 43 - Encourages learning and development of employees (courses, trainings, seminars); question 44 - Collaborators know his opinion on the problems of personal and business nature; question 45 - without a formal position in the organization, he would have difficulty communicating with people.

Questions 46 and 47 had similar distributions of the response with the median $\mathrm{Me}=4$, while with a more negative connotation were questions 48,49 and 50 , but the value of median $\mathrm{Me}=4$ was maintained.

Questions used in this block are following: CLAIM - In our organization my manager internally communicates by doing so: question $46-\mathrm{He}$ is able to listen to different opinions and find a common, acceptable solution; question 47 - Allows subordinates to express their opinions without interrupting; question 48 - When communication goes in an unwanted direction, he remains consistent with his attitude; question 49 - He does not make decisions until the strategy is determined from the top of the organization; question 50 - He gives attention to the thoughtful communication with the subordinates.

Good communication (GC) expressed through the answers received $\mathrm{Me}=4$ in questions 51 and 52, while very positive attitudes are given in question 53 where $\mathrm{Me}=5$, and somewhat less positive attitudes 
Figure 8. Answers to questions $31-35$

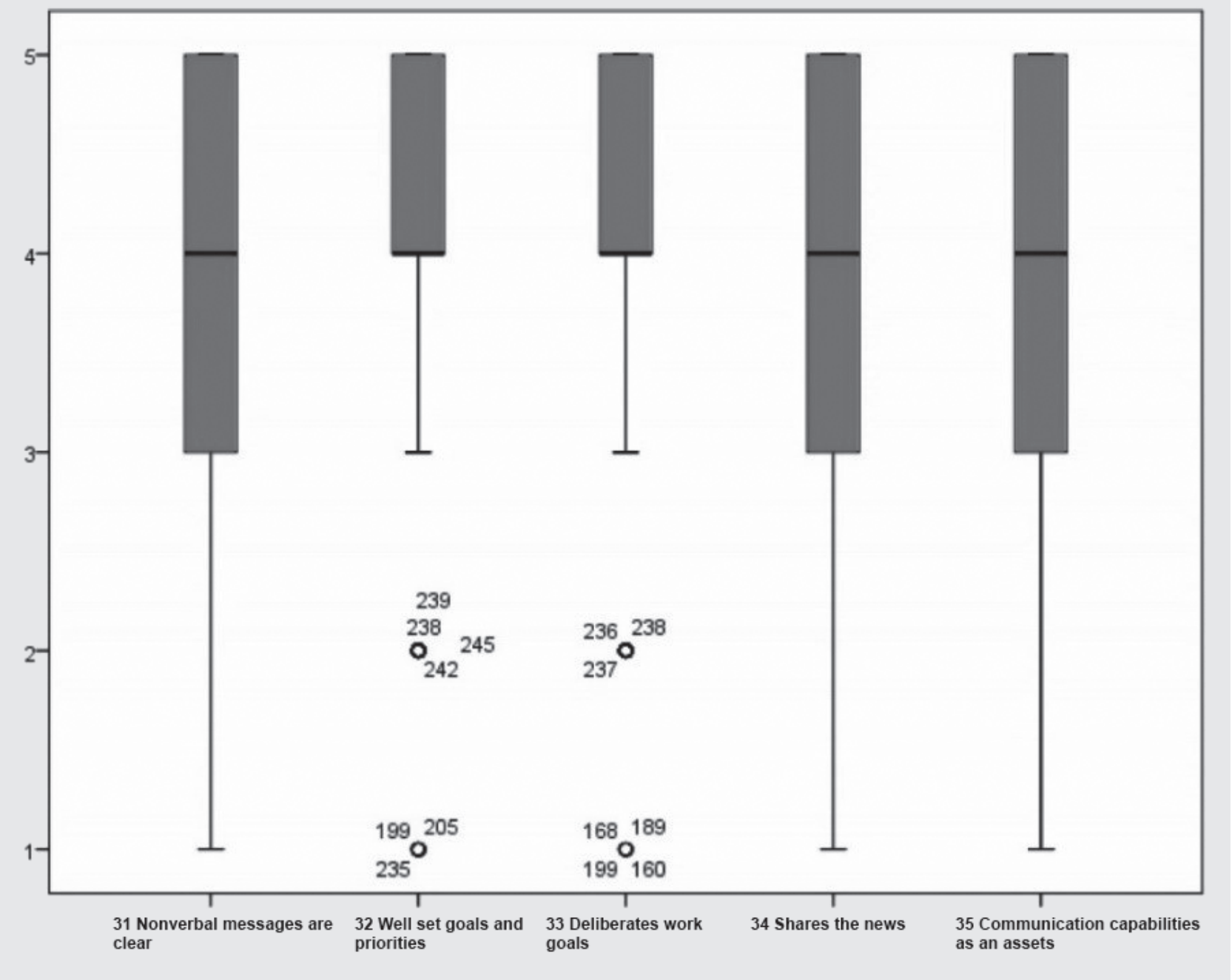

(but more positive than other questions) are for question 54 where $\mathrm{Me}=4$. Question 55 was in line with questions 51 and 52 .

Questions used in this block are following: CLAIM - In our organization my manager internally communicates by doing so: question 51 - He thinks that a good communion with subordinates contributes to the success of the organization; question 52 - He believes that good communication motivates and additionally encourages employees to work; question 53 - Good communication is one of the important conditions for overcoming the problem; question 54 - Good communication is the basic precondition for increasing the profitability of the company; question $55-\mathrm{He}$ believes that it is necessary for all employees to know the vision, mission and goals of the organization.

\section{CONCLUSION}

The results confirmed the general hypothesis that internal communication contributes to the success of the organizations efficiency and functioning, which could lead to the creation of a modern model of efficient internal communications.

Also, the results confirmed the first individual hypothesis that internal communication is clearly directed towards the goals of the organization. According to the results of the internal research on the employees attitudes at the company Dunav osiguranje, the majority of respondents are mostly or completely fully aware of the organization goals and communication plan, the tasks are transferred to the company through precise written communication, and there is also openness for different attitudes and opinion by the employees. Major disagreement to the general tone of 


\section{marketing}

FigurE 9. Answers to questions $36-40$

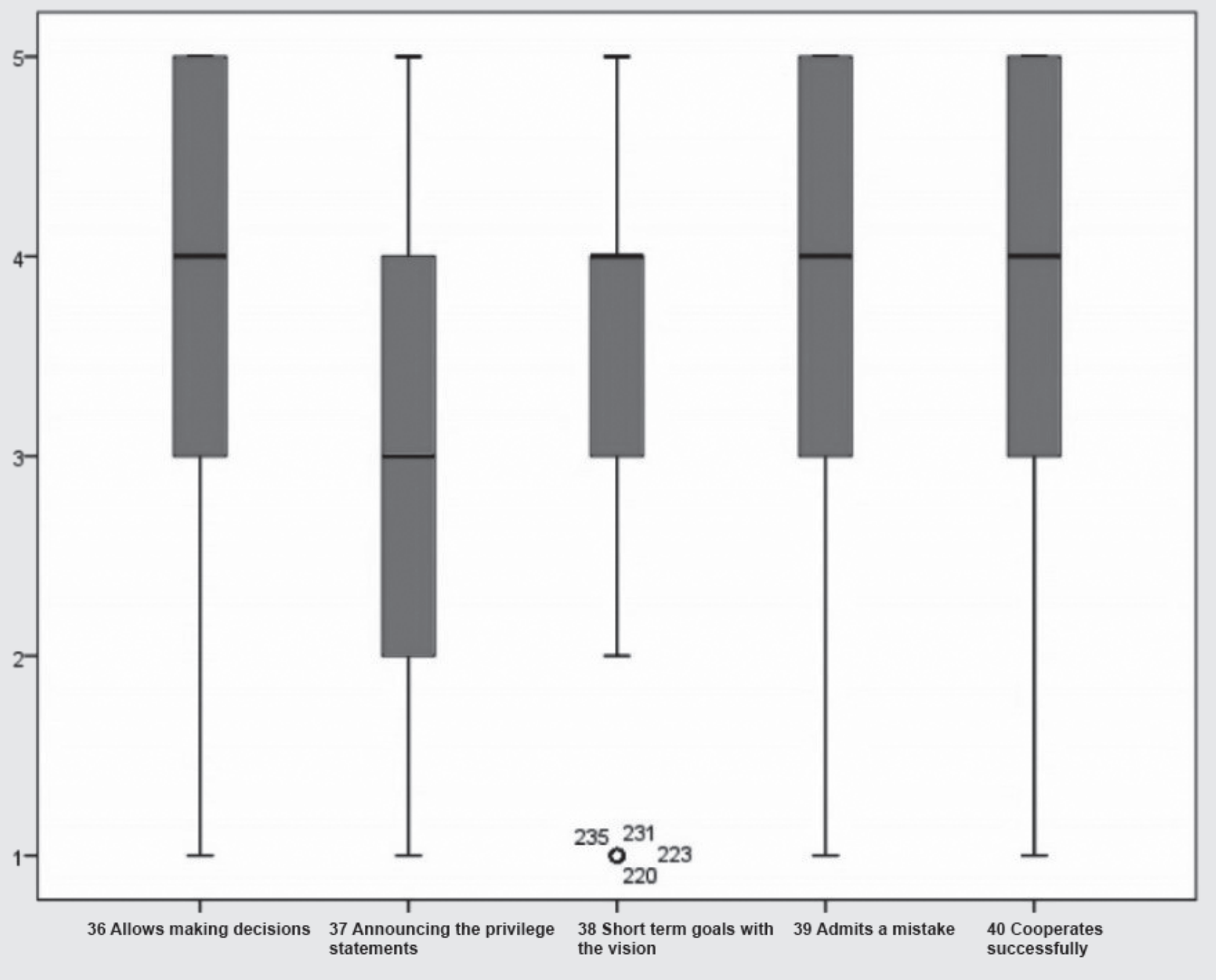

answers was observed with those of elderly employees and in lower positions.

The second individual hypothesis that the leader's behavior affects the communication and employee efficiency is proven through the results of the research. The answers point to the fact that the managers do regularly inform the employees about the overall company functioning, the business results, which allows the whole organization to be up to date, to function seamlessly. This immediately affects the efficiency of the company.

The answers also show that the managers are ready to listen to the ideas and thoughts of the subordinates, and to set aside the time for some informal socializing. Such venues and opportunities lend themselves to informal communication about the work, which is less structured but packed with more subjective and emotional intensity, assisting the employees to be more incentivized to be more efficient.

To a lesser extent the employees feel that the managers are ready to hear their colleagues' personal problems. But overall there is employee satisfaction with leader's communication and are connecting the behavior of leaders to communication and to the of the organization.

Furthermore, the research shows that important decisions are mostly a result of teamwork, with the manager consulting with his subordinates on issues at hand. Such business decisions are then easier to implement and influence a more productive workflow. Managers are also seen as able to keep the staff under control, not to let things get out of control. This indicates the existence of discipline in the organization in order to allow it to function well. To a great extent, the manager is seen as someone who speaks the truth 


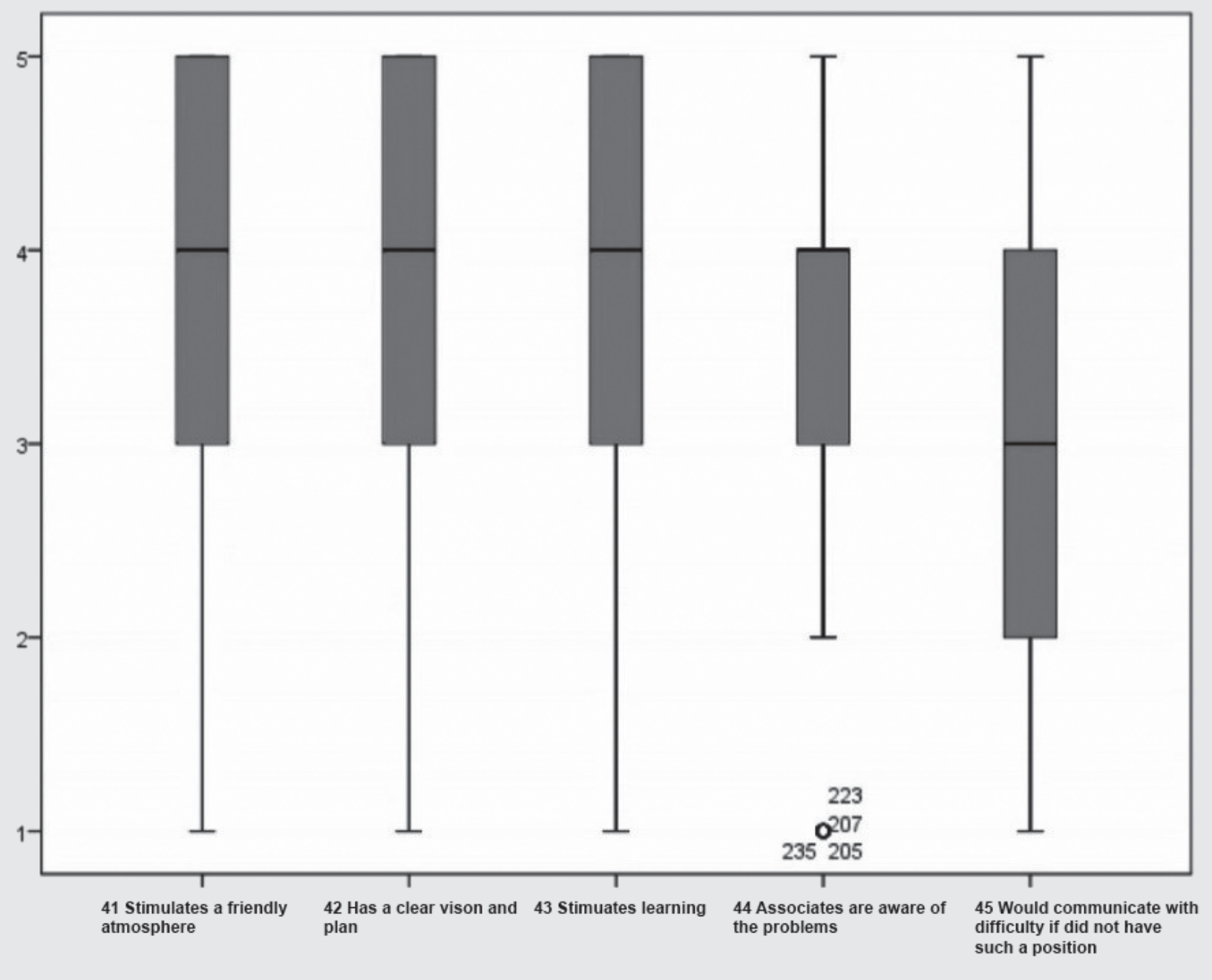

and the facts, thus for this reason, their authority is real, not a formal one. The manager determines the role of each team member and uses the opportunity to compliment the associates for good results. They are open to communication and regularly communicate their opinion. The managers are seen as maximally adhering to company rules and standards. The results of the survey indicate that a lesser shortcoming has been identified in that the staff is not sanctioned to the right extent. The managers are perceived as the ones who set the goals and priorities well and share the company news with the team members. The staff recognizes the communicativeness of the managers as a benefit. The managers cooperate successfully and are able to acknowledge their own errors almost every time, or all the time.

The third individual hypothesis that the working atmosphere needs to supportive and constructive in order to provide for efficiency has also been confirmed. Internal communication is seen as overall very positive considering that the managers do stimulate the working atmosphere, have a clear vision and plan, they are seen as to encourage employees to learn, informing them about problems in terms of joint solution finding. The managers have the authority from the employees especially because of such an attitude towards the employees, not because of their formal position. The managers are seen to pay attention to the thoughtful communication within the company. They are seen as not to make their final decisions until the top management decides on a topic first. They are seen to be consistent in their attitudes, but also listen to other opinions and allow the expression of others' opinions. Employees also have answered that they have the awareness of the importance of good communication to overcome the problems in functioning 
FiguRE 11. Answers to questions $46-50$

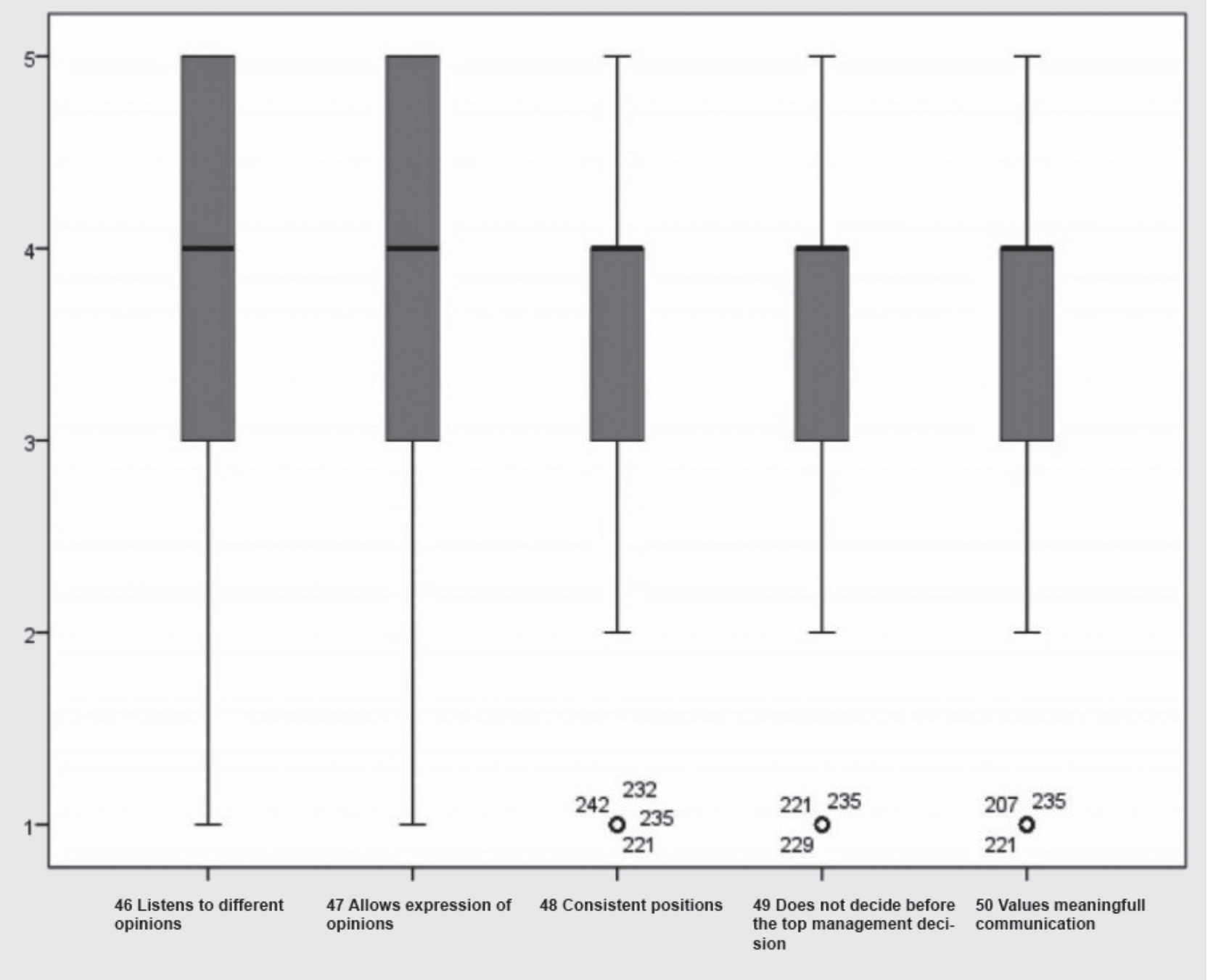

of the company, and that communication clearly contributes to success and is a prerequisite for profitability. Most also agree that everyone needs to know the vision and mission of the company.

The conducted research confirms the importance of a planned and systematically conducted communication process with the employees in the company in order to spur efficiency. To function efficiently the employees, need to be heard and their opinions consulted. Therefore, mutual trust is relevant and also needed in efficient working environment. Trust is one of the most important benefits of good internal communication. Trusting "outside" and "from the inside“ means that employees who have mutual trust within an organization intrinsically, inevitably transfer this confidence to the outside directly in contact with clients, business partners, suppliers, and indirectly through people they daily contact in an informal gathering. It is a process in which all participants are equally important at the level at which they are located and with whom they communicate, in which the communications flow (in all directions) in an uninterrupted manner.

The success of an organization is still measured largely by its financial and market success, which is a result of many factors, of which efficiency is extremely relevant. The quality of intangible values and accountability to employees is very much an element in the success also. Increasingly, the organization's success depends on how quickly it manages to establish communication with the internal publics and how it manages to bring all employees together for a common goal, in order to conduct a quick and efficient implementation of decisions its business strategy.

Communication is the key to all aspects of change in the modern world. The personal level is equated 
FigurE 12. Answers to questions $51-55$

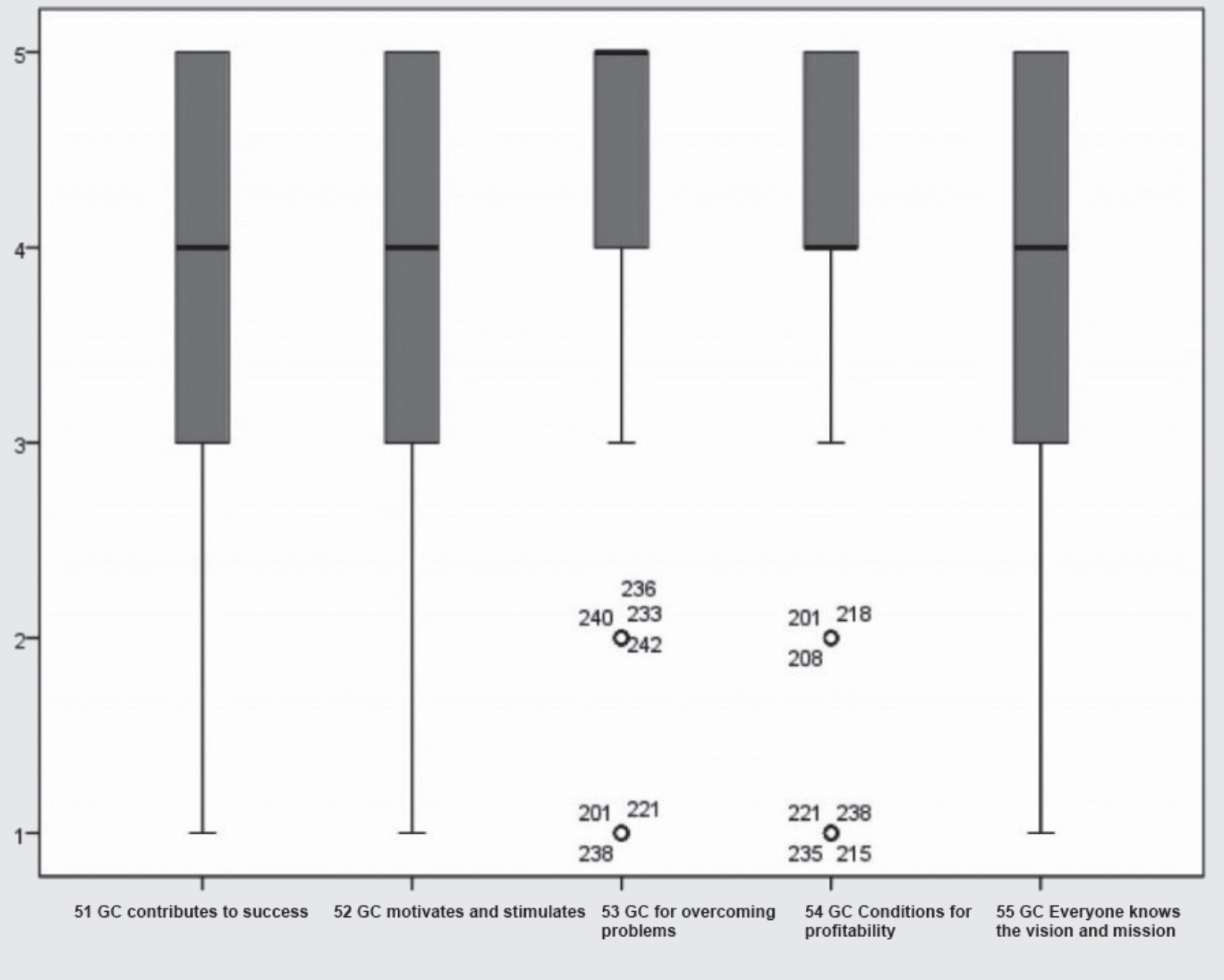

with the global one, which puts the process of personal, internal development of each individual, internal and external relations of each organization and global social progress into the same plane. The essence of communication effort is to gain the other party's cooperation, and the key to successful cooperation is the communication skills. For the successful conduct of any communication, the willingness and readiness for interpersonal contact must be expressed, because relations among people in general, and in the organization in particular, depend on how much they manage to establish mutual communication.

\section{References}

1. Buhler, M. P., \& Worden, J. D. (2013). Up, Down, and Sideways: High-Impact Verbal Communication for HR Professionals. Society for Human Resource Management, Alexandria, Virginia.

2. Cornelissen, J. (2011). Corporate communication: A guide to theory and practice. London: SAGE Publications.
3. Chalmers, S. (2008, October). The Changing Role of Internal Communications. Are Required Practitioner Competencies Keeping Pace with the Opportunities and Challenges? Paper presented at Euprera (European Public Relations Education and Research Association) 2008 conference, Milan, 16th - 18th October 2008. http://eresearch.qmu.ac.uk/568/ 
4. Dolphin, R. (2005). Internal Communications: Today's Strategic Imperative. Journal of Marketing Communications, 11(3), 171-190. https://doi. org/10.1080/1352726042000315414

5. Filipović, V., \& Kostić-Stanković, M. (2008). Odnosi s javnošću, FON, Beograd.

6. Grossman, D. (2012). You Can't NOT Communicate. The David Grossman Group, Chicago

7. Grunig, J.E., (1992). Symmetrical systems of internal communication, in Grunig, J.E., Dozier, D.M., Ehling, W.P., Grunig, L.A., Repper, F.C. \& White, J. (Eds). Excellence in Public Relations and Communication Management, Lawrence Erlbaum Associates, Hillsdale, NJ, pp. 531-575.

8. Grunig, L.A., Grunig, J.E. and Dozier, D.M. (2002). Excellent Public Relations and Effective Organizations: A Study of Communication Management in Three Countries. Lawrence Erlbaum Associates, Mahwah, NJ.

9. Hola, J. (2007). The Importance of Internal Company Communication. Ekonomika ir vadyba: aktualijos ir perspektyvos. 1(8), 107-111.

10. Jacobs, M. A., Yu W., \& Chavez, R. (2016). The effect of internal communication and employee satisfaction on supply chain integration. International Journal of Production Economics, 171(1), 60-70. https://doi. org/10.1016/j.ijpe.2015.10.015

11. Jiang, H., \& Men, L.R. (2015). Creating an engaged workforce: the impact of authentic leadership, transparent organizational communication, and work-life enrichment. Communication Research. https://doi.org/10.1177/0093650215613137

12. Kamalirad, S., Kermanshachi, S., Shane, J., \& Anderson, S. (2017, November). Assessment of construction projects' impact on internal communication of primary stakeholders in complex projects. 6th CSCE/CRC International Construction Specialty Conference, Leadership in Sustainable Infrastructure, Vancouver, Canada.

13. Katlip, M., S., Senter, H., A., \& Brum, M., G. (2006). Uspesni odnosi s javnoscu, Sluzbeni glasnik, Beograd.

14. Kanyurhi, E. B., \& Akonkwa, D. B. M., (2016). Internal marketing, employee job satisfaction, and perceived organizational performance in microfinance institutions. International Journal of Bank Marketing,
34(5), 773-796. https://doi.org/10.1108/IJBM-062015-0083

15. Kim, J. N., \& Rhee, Y. (2011). Strategic thinking about employee communication behavior (ECB) in public relations: testing the models of megaphoning and scouting effects in Korea. Journal of Public Relations Research, 23(3), 243-268. doi: 10.1080/1062726x.2011.582204.

16. Meyer, J. (2014). Employee Commitment, Motivation, and Engagement: Exploring the Links. Article in Gagné, M. (ed.) The Oxford handbook of work engagement, motivation, and self-determination theory. Oxford: Oxford University Press. 33-36.

17. Men, L.R. (2014). Why leadership matters to internal communication: linking transformational leadership, symmetrical communication, and employee outcomes. Journal of Public Relations Research, 26(3), 256-279.

18. Men, L.R. (2015), Employee engagement in relation to employee-organization relationships and internal reputation: effects of leadership communication. Public Relations Journal, 9(2),85-95.

19. Mikic, A., (2010, March). Uloga interne i eksterne komunikacije u menadžmentu poslovnih organizacija. Međunarodna naučna konferencija 'Menadžment 2010", Krusevac, Serbia.

20. Mishra, K., Boynton, L., \& Mishra, A. (2014). Driving Employee Engagement: The Expanded Role of Internal Communications. International Journal of Business Communication, 51(2), 183-202.

21. Morris, E. (2010). Dell goes mobile to bolster its employee engagement. PRWeek, 13(2), 14-15.

22. Sincic D., \& Poloski-Vokic N. (2007). Integrating internal Communications, human resource management and marketing concepts into the New internal marketing philosophy, Working Paper No 0712, University of Zagreb.

23. Waters, R. D., Bortree, D. S., \& Tindall, N. T. J. (2013). Can public relations improve the workplace? Measuring the impact of stewardship on the employer-employee relationship. Employee Relations, 35(6), 613-629.

24. Welch, M., \& Jackson, P. R. (2007). Rethinking internal communication: a stakeholder approach. Corporate Communications an International Journal, 12(2), 177-198. 


\section{Apstrakt}

\section{Interne komunikacije kao faktor efikasnosti kompanije}

Milica Slijepčević, Ana Bovan, Ivana Radojević

Polazno pitanje u radu jeste: kako organizacija mora da se postavi u procesu internih komunikacija da bi u sve turbulentnijem i konkurentnijem okruženju, ostala jedinstvena, prepoznatljiva i uspešna? Glavni cilj ovog rada je da prezentuje savremene trendove u internim komunikacijama i način na koji utiču na efikasnost organizacije. Istraživanje je utemeljeno na postojećoj literaturi predstavljajući interne komunikacije i njihov uticaj na efikasnost zaposlenih u organizaciji. Takođe, autori će prikazati rezultate istraživanja koje je usmereno na interne komunikacije u okviru kompanije Dunav osiguranje. Ideja za ovaj rad je proistekla iz nužnosti unapređenja internih komunikacija u skladu sa brzim tehnološkim promenama i zahtevima tržišta. U okviru istraživanja anketirano je 255 ispitanika iz svih organizacionih celina kompanije Dunav osiguranje. Istraživanje predstavljeno u radu potvrđuje značaj procesa komuniciranja sa zaposlenima u kompaniji i njegov uticaj na efikasnost procesa rada. Ovaj rad proširuje postojeća istraživanja u vezi sa internim komunikacijama i organizacionom efikasnošću ističući praktičnu važnost, dosledne i dobre komunikacije sa zaposlenima na samo poslovanje.

Ključne reči: Interne komunikacije, komunikacija sa zaposlenima, korporativne komunikacije, efikasnost, proces rada

\section{Kontakt}

Milica Slijepčević, milica.slijepcevic@metropolitan.ac.rs Ana Bovan, ana.bovan@metropolitan.ac.rs Ivana Radojević, ivana.radojevic@metropolitan.ac.rs 